ECONOMICS

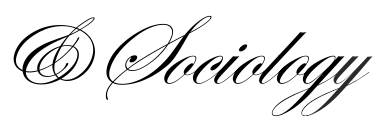

Sulphey, M.M. (2020). Construction and validation of Workplace Identity Scale (WIS). Economics and Sociology, 13(2), 53-69.doi:10.14254/2071-789X.2020/13-2/4

\title{
CONSTRUCTION AND VALIDATION OF WORKPLACE IDENTITY SCALE (WIS)
}

\author{
Sulphey, M. M. \\ College of Business Administration, \\ Prince Sattam Bin Abdulaziz. \\ University, \\ AlKharj, Saudi Arabia \\ E-mail: \\ s.manakkatti@psau.edu.sa \\ ORCID 0000-0001-6042-2123
}

Received: October, 2019

1st Revision: May, 2020

Accepted: June, 2020

DOI: $10.14254 / 2071-$

789X.2020/13-2/4

JEL Classification: M54, J89

\begin{abstract}
Workplace identity (WI) is a multi-dimensional and multi-layered construct that originated from the concept of Identity. It is an attitude towards self that helps individual employees to identify themselves as crucial members in the organisation by shaping their roles in the employment context. Empirical examination of the construct is now gaining traction. A scientifically validated tool is likely to provide further impetus to detailed examinations of the WI concept. The present study is intended to construct and validate a tool to measure WI. Using the data collected from a sample of 248 respondents and the well established methodologies, this study constructs and validates a scale to measure WI - the Workplace Identity Scale (WIS). Having five factors, this scale has exhibited significant validity and reliability. WIS is expected to fill the gap in literature and is likely to stimulate further empirical research about this alluring construct.
\end{abstract}

Keywords: workplace identity, scale construction, scale validation

\section{Introduction}

The concept of workplace identity (WI) is gaining traction in management literature (Sulphey, 2019). It describes one's self-concept based on the understanding of the work role. The concept "links thoughts and actions, cognitive processes and behaviours and takes not account the ways through which identities are formed" (Walsh, 2000). WI can significantly influence employee behaviour and outcomes (Amiot et al., 2007; Hozouria et al., 2018; Riemenschneider et al., 2019; Worth, 2019) and positively impact organisational performance (Agostino, 2004; Wayne et al., 2006). It provides employees with a sense of positive feeling, derived from doing right and ethical things. Hence employees identify themselves as crucial organizational members (Sulphey, 2019). According to Dutton et al., (1994), WI is derived from "social identity", as employees are de facto members of a number of "social groups". Their identities are formed based on the type and quality of their respective membership. A clear assessment of WI may help individuals and organisations in various ways. Therefore, there is a definite need for an appropriate tool to assess WI. The main purpose of this paper is to construct and validate a tool for assessing WI. To reach this research objective, the following tasks were accomplished: the review of literature, creation of an item pool, collection of data, 
item reduction, exploratory and confirmatory factor analyses, and finally, reliability and validity tests. As we are dealing here with a relatively new concept, difficulties were faced with respect to finding experts in the field to provide opinions for refining the item pool. Extreme caution was exercised at all the stages of this research.

\section{Literature review}

Before discussing WI, it would be imperative to have a short discussion about the concept of 'Identity'. Identity is a complex concept that is receiving wide attention and research interest (Albert et al., 2000; Hogg et al., 1995; Van Laar et al., 2019). Many social scientists have attempted to define the concept. According to Hewitt (1989) identity is:

"a sense of continuity, integration, identification and differentiation constructed by the person not in relation to a community and its culture but in relation to the self and its projects".

VanStaden (2005) defined it as "the characteristics that set one apart from another as a unique being". However, there seems to be a lack of consensus about identity as it is used in varying contexts (Bothma et al., 2015). It is "fluid and malleable, rather than fixed" (Giddens, 1991) and "ambiguous and slippery" (Bauman, 2004). Identity develops through a complex cognitive interaction between the individual and the social foci/life spheres (Botma, 2011). According to Bothma et al., (2015) identity formation is succeeded by two other processes identity activation and resultant behaviour. Identity formation process could vary, and be based on the individual who owns a set of unique characteristics and capabilities. Having a separate identity enhances an individual's sense of belongingness (Ashforth \& Mael, 1989; Hogg \& Terry, 2000). Successful construction, transformation and maintenance of identity enhance the feeling of belongings to groups - including work groups (Agostino, 2004; Kirpal, 2004). This proposition has profound proximity with WI.

\section{WI}

WI is derived from "social identity", as individual employees are de facto members of various social or work group(s) (Alvesson \& Willmott, 2002; Dutton et al., 1994). In ordinary parlance WI is the different ways an individual identifies himself within the work context (Fugate et al., 2004). It is the psychological relationship between an individual with his organization. Elsbach (2004) defined it as "an individual's central and enduring status and distinctiveness" at workplace.

According to Buche $(2003,2008)$, WI is "a socially constructed representation of an individual's self-perception of his/her own interactions within the employment environment". Agostino (2004) defined it as "the sense of individual identity that an employee derives from being part of a particular workplace". Walsh \& Gordon (2008) defined WI as "a work-based self-concept constituted of a combination of organisational, occupational and other identities" (p. 2). The definition of Lloyd et al., (2011) was modified by Bothma \& Roodt (2012) as:

"a multi-identity, multifaceted and multilayered construction of the self (in which the self-concept fulfils a core, integrative function), that shapes the roles of individuals who are involved in an employment context".

WI is thus a multi-dimensional/layered phenomenon (Baugher, 2003; Kirpal, 2004) about self that helps individual employees to identify themselves as crucial members in the organisation, and shaping their roles in the employment context (Bothma \& Roodt, 2012; Roodt 
\& Odendaal, 2011). It describes one's self-concept and the understanding, based on the work role.

\section{Benefits and importance of WI}

WI, according to Amiot et al., (2007) significantly influences employee behaviour, and resultant work and organizational outcomes. It also positively impacts organisational performance (Agostino, 2004; Wayne et al., 2006); as each individual is tied organically with social identities to their groups, and mechanically within their groups through their role identities. Collective WI of any organization profoundly impacts the overall performance of organisations (Ashforth \& Kreiner, 1999; Agostino, 2004; Brown \& Bimrose, 2018; Wayne et al., 2006). Its importance can be judged from its interconnections and relationships with multitude of OB concepts like job involvement and job commitment (Bothma \& Roodt, 2012; Sandhya \& Sulphey, 2020), turnover intention, task performance (Bothma \& Roodt, 2012; Hegde, 2016; Sandhya \& Sulphey, 2019), etc. The various benefits of WI are presented in Table 1 .

Table 1. Benefits of WI

\begin{tabular}{ll}
\hline \multicolumn{1}{c}{ Author } & \multicolumn{1}{c}{ Details } \\
\hline Staples et al., (1984) & $\begin{array}{l}\text { Creates positive feeling among employees due to doing right and } \\
\text { ethical things } \\
\text { Employees identify themselves as crucial members in the organisation }\end{array}$ \\
\hline $\begin{array}{l}\text { Buche (2003) } \\
\text { Walsh \& Gordon (2008) }\end{array}$ & WI influences the level of job satisfaction among employees \\
\hline $\begin{array}{l}\text { Agostino (2004); Wayne et } \\
\text { al., (2006) }\end{array}$ & Organisational performance is significantly and positively influenced \\
\hline Amiot et al., (2007) & $\begin{array}{l}\text { Significantly influences employee behaviour impacting the subjective } \\
\text { work and objective organisational outcomes }\end{array}$ \\
\hline Caza \& Wilson (2009) & $\begin{array}{l}\text { An energy resource for organizations and precursor for further } \\
\text { resources }\end{array}$ \\
\hline
\end{tabular}

Source: Author's compilation

Despite the fact that adequate literature has evolved about WI, a validated and scientific measuring tool is yet to be constructed. Though review of literature has provided a few tools to measure WI, there seems to be lack of validation of the available tools. The present study attempts to fill this gap in literature.

\section{Objective}

The objective of the present work is to develop and standardize a Workplace Identity Scale (WIS). Though many social scientists have attempted to measure WI (Buche, 2003, 2008, Walsh \& Gordon, 2008; Wayne et al., 2006), there is paucity of scientifically validated multidimensional instrument. Bothma \& Roodt (2012), who have done considerable work in WI, is of the opinion that "no suitable measuring instrument was found that complied with the requirements of the theoretical definition of WI". Previous researchers relied on items put together in an ad hoc manner (e.g., Banerjee, 2013). These scales are too brief with very few items. For instance the scale by Banerjee (2013) consisted of eight items. The work merely mention about Alpha, with scant reference about construction or validation. Another scale by Cortini (2016) consists of five items (Cronbach's alpha of 0.91). A scale that is worth 
mentioning is that of Bothma \& Roodt (2013). The scale was developed by adapting and combining five different scales or part of the scales that measured varying facets of WI. The items were identified from Organisational-related commitment scale (Roodt, 1997), Job involvement scale (Lodahl \& Kejner, 1965), Functions of identity scale (Serafini et al., 2006), Organisational identification scale (Mael \& Ashforth, 1992), and Person-organisation fit scale (Lauver \& Kristof-Brown, 2001). The original scale of 36 items after Factor analysis (FA) yielded 28 items. The scale reported Cronbach's Alpha of .946. It seems ironical that though the items were sourced from various scales, the exploratory FA provided only uni-dimensional solution.

As a fair review thus failed to identify any ideal and scientifically developed scale to measure WI, a new tool was sought to be developed. Further, since the concept of WI included various facets or dimensions (Bothma, 2011; Bothma \& Roodt, 2013) it is plausible that the tool ought to be multi-dimensional. It is proposed and expected that the proposed tool would be multi-dimensional in nature, and capable of measuring WI precisely.

\section{Methodology}

Multiple studies have provided directions about the scientific process of constructing empirically strong psychometric tools (Clark and Watson, 1995; Kumar \& Beyerlein, 1991; Hinkin, 1998; Schwab, 1980). The main stages are item generation, scale development, followed by evaluation. The current study has attempted to closely follow the steps presented in these studies. The steps followed are item development, data collection, scale development, and evaluation.

\section{Creation of item pool}

The guidelines provided by Hinkin $(1995,1998)$ were followed for creating an initial item pool. Since the scale length weigh against quality responses (Sulphey, 2016), determining the ideal number of items was accorded top priority. Hinkin (1995) noted that too long or short scales are likely to have potentially "negative effects on results". Anastasi (1976) and Schriesheim \& Eisenbach (1991) view having a short scale is the best way of dealing with "demands in terms of time, and minimizing response biases that could occur as a result of boredom and fatigue". According to Cook et al., (1981) internal consistency reliability is possible with lesser items (even three). Hinkin (1995) and Nunnally (1978) opine that lesser items could lead to a lack of content and construct validities, as well as reliability and internal consistency. There is definite need for proper domain sampling and parsimony, as it helps in content and construct validities (Cronbach \& Meehl, 1955). Maintaining scale length at appropriate level has the advantages of minimizing response bias, and ensuring internal consistency reliability (Hinkin, 1995). Based onthese, due care was exercised to ensure that the tool is neither too short nor long. This will also help in constructing a meaningful and fecund tool (Sulphey, 2014).

The items for the study were identified based on relevant literature and available tools, and discussions with experts. These are absolute requirements for content validity (LopezFernandez et al., 2014; and Tossell et al., 2015). Since content validity is based on expert judgement and not a statistical property, author judgement and discretion plays a dominant role. For content validity, the stipulations of Bearden et al., (1993) were followed closely. Domain sampling and parsimony were given the due focus, while identifying the initial items. According to Cronbach \& Meehl (1955) content and construct validities are not possible, if domain sampling and parsimony are lacking. 
A detailed review of literature pointed that the domains of WI tend to diverge with each researcher. For instance, Kirpal (2004) identified three dimensions of WI - structural, social, and individual psychological components. Lloyd et al., (2011) opined that working individuals operate in three core contexts - life spheres, life roles and work contexts. Johnson et al., (2012) identified three factors of WI - individual, relational, and collective identities. Bester (2012) identified work centrality, value congruence and person-organization fit as the three domains.

Based on the various domains identified from earlier studies, a pool of 33 items under five domains was created. These domains were identified based on the review of literature, and with a view of providing a comprehensive outlook to the construct. The pool was refined with expert help, to confirm that it covered relevant domains of WI. The experts confirmed that the domains and items covered all the aspects of the construct. These are prerequisites to ensure content and face validities. As per expert opinion, a few items were eliminated, with a resultant initial pool of 28 items. Sample items from each domian are: Job centrality - I am valued because of my work. Self identity - I find myself as an integral part of my organization. Personorganization fit - I consider my organization's success as my own. Job-fit - I consider my job as an important part of my life. Collective identity - In my organization, I feel of being an integral part of the group I work with. As stated earlier, these domains were identified based on review of relevant literature and expert opinion. Care was exercised to see that items were understood as desired by the researcher, in addition to giving due importance to aesthetics. These properties are essential for face validity.

\section{Scaling}

Since scaling offers the required inputs for statistical analysis, it should be decided with utmost care and caution. Any scaleshould generate required variance from amongst the respondents (Hinkin, 1995). Scaling devoid of variance cannot be statistically analysed. Scaling normally utilizes ranges between three and 10 on Likert-type scales. Since Cronbach's alpha (Nunnally, 1978) increases up to five scales and thereafter levels off (Lissitz \& Green, 1975), a five point scale was adapted for the study.

\section{Sampling}

Determining sample size is of paramount importance and the most difficult in any statistical study (Lenth, 2001). Adequate size is essential to provide significant results capable of appropriate statistical inferences (Hinkin, 1995). Larger samples are indispensible for conducting powerful statistical tests (Stone, 1978). However, if it is too big, there would be an effect of little scientific importance (Lenth, 2001). The appropriate sample size has been a matter of hot and serious discussion among academic circles (Hinkin, 1995; Lenth, 2001; Odeh $\&$ Fox, 1991). The adequateness of sample size required for conducting FA has also been discussed by many (Hinkin, 1995; Hoelter, 1993; Schwab, 1980; Viswanathan,1993). Quantifying the minimum acceptable sample size, Hoelter (1993) proposed 200 samples; and Hinkin (1995) 150. Hinkin (1995) and Viswanathan (1993) have even proposed sample size less than 100. Schwab (1980) opines that for conducting FA, 1:10 is the ideal item-to-response ratio; and Rummel (1970) suggested 1:4.

Utmost case is required for sample designing for accurate portrayal of the essential characteristics of the population. It has to yield maximum possible precision with minimum variance. The present study has provided utmost care in the formulation, identification and selection of samples. 


\section{Data collection}

The questionnaire was administered online through Google docs to Indian volunteers who were gainfully employed in, service, banking and manufacturing organizations, in the state of Kerala, after obtaining their willingness. This ensued that no items were left without being responded. Data for the present study was collected from 248 respondents. 145 (58.5\%) were males and $103(41.5 \%)$ females. The minimum age of the respondents was 21 and the maximum 60 years (mean 33.42). Experience in the current organization ranged between 3 months and 38 years (mean 7.02), and the overall of experience ranged from six months to 41 years (mean 10.05). There was also wide diversity in terms of educational qualifications and type of organization in which they worked. These aspects point towards diversity of the sample, which will aid in providing validity.

\section{Item reduction}

Refining and item reduction of a scale could be done using inter-item-correlation and FA (Boyle, 1991; Hinkin, 1995, 1998). Boyle (1991) suggested the elimination of items for which inter-item-correlations exceeds .70. According to him, such elimination "could help in avoiding too much redundancy and artificially inflated estimates of internal consistency". The 28 items of the present study were subjected to inter-item correlation. No items were eliminated, as none of the correlation values exceeded .70. The item-to-total correlation was then calculated. According to Kim \& Mueller (1978) and Kumar \& Beyerlein (1991) only those items with higher item-to-total-correlation (r over .40) are retained. The assumption behind this is that items belonging to common domain exhibit similar average correlations. Low correlations would indicate that items do not belong to the appropriate domain, which may result in questionable reliability (Churchill, 1979). This exercise resulted in eliminating four items. This method of elimination has also been done in various earlier studies (Sulphey, 2014; Sulphey, 2015; Sulphey \& Faridi, 2020). The resultant questionnaire with higher item-to-total correlation consisted of 24 items (correlation ranged from .401 to .714).

The Kaiser-Meyer-Olkin (KMO) and Bartlett's Test helped in assessing sampling adequacy for conducting FA (Kaiser, 1974). While KMO value above .90 is considered best, any value below .60 is unacceptable (Hair et al., 1998). According to Olkkonen \& Saastamoinen (2000) if KMO is greater than 0.90 , it is considered as "excellent premises", any value greater than 0.80 is "good premises" and over 0.70 is "moderate premises". The KMO value for the present study was found to be .874 . By the measures of Hair et al., (1998) the KMO qualifies for sampling adequacy. Based on Olkkonen \& Saastamoinen (2000) standards, KMO value of .874 denotes "good premises". The Bartlett's Test of Sphericity Chi-square value was 1806.496, which was significant. These values indicate appropriateness of data for conducting EFA.

\section{Results}

Subsequent to item reduction, exploratory and confirmatory factor analyses were conducted. The details of the factor analyses are presented in the following sections. This is folowed by the details about the reliabiities and validities of the scale. 


\section{Exploratory FA}

EFA was conducted using principal component axis and Orthogonal (Varimax) rotation method with Kaiser Normalization. Ford, et al (1986) and Hinkin (1995) stipulated a minimum factor loading of .40; which was followed in this study. Based on Eigen values, five factors were extracted. Since three items had heavy cross loadings, they were dropped, and EFA was re-run. This resulted in a five factor solution (Table 2).

Table 2. Items and factor loadings of WIS

\begin{tabular}{|c|c|c|c|}
\hline No & Items & $\begin{array}{l}\text { Factor } \\
\text { loading }\end{array}$ & $\begin{array}{l}\text { Item-to-total- } \\
\text { correlation }\end{array}$ \\
\hline \multicolumn{4}{|c|}{ Factor 1 Job centrality (JCA) } \\
\hline A1 & I am valued because of my work & .744 & .642 \\
\hline $\mathrm{A} 2$ & My work is the most important aspect of my life & .744 & .578 \\
\hline A3 & Without my job I don't have any identity & .698 & .407 \\
\hline A4 & All my achievements are directly related to my job & .655 & .599 \\
\hline A5 & $\begin{array}{l}\text { I am more known in the society, because of my job in my } \\
\text { organization }\end{array}$ & .487 & .581 \\
\hline \multirow[t]{3}{*}{ A6 } & I am something in life because of my organization & .476 & .639 \\
\hline & Eigen value & 6.770 & \\
\hline & $\%$ variance explained & 32.328 & \\
\hline \multicolumn{4}{|c|}{ Factor 2 Self identity (SIB) } \\
\hline B1 & My values and organizational values match each other & .751 & .539 \\
\hline B2 & In my job, I have the freedom to decide what to do & .667 & .477 \\
\hline B3 & I will recommend my organization to others & .648 & .612 \\
\hline B4 & My job prevents me from becoming what I want to be & .527 & .401 \\
\hline \multirow[t]{3}{*}{ B5 } & I find myself as an integral part of my organization & .455 & .714 \\
\hline & Eigen value & 1.784 & \\
\hline & $\%$ variance explained & 8.495 & \\
\hline \multicolumn{4}{|c|}{ Factor 3 Person-organization fit (IOFC) } \\
\hline $\mathrm{C} 1$ & $\begin{array}{l}\text { When someone praises my organization, I feel it as my personal } \\
\text { accomplishment }\end{array}$ & .794 & .599 \\
\hline $\mathrm{C} 2$ & I am interested in what others think about my organization & .748 & .446 \\
\hline C3 & If someone criticizes my organization, I feel personally insulted & .692 & .549 \\
\hline & I consider my organization's success as my own & .546 & .650 \\
\hline & Eigen value & 1.440 & \\
\hline & $\%$ variance explained & 6.859 & \\
\hline \multicolumn{4}{|c|}{ Factor 4 Job fit (JFD) } \\
\hline & The work I do at my organization is meaningful & .706 & .529 \\
\hline D2 & My work is a rewarding activity for me & .663 & .483 \\
\hline & I consider my job as an important part of my life & 619 & .523 \\
\hline & Eigen value & 1.114 & \\
\hline & $\%$ variance explained & 5.304 & \\
\hline \multicolumn{4}{|c|}{ Factor 5 Collective identity (CIE) } \\
\hline & When I talk about my organization, I often say "we" & .723 & .488 \\
\hline & I contribute my maximum to grouptasks & .653 & .534 \\
\hline & $\begin{array}{l}\text { In my organization, I feel of being an integral part of the group I } \\
\text { work with }\end{array}$ & .524 & .553 \\
\hline & Eigen value & 1.007 & \\
\hline & $\%$ variance explained & 4.796 & \\
\hline
\end{tabular}

Note $\quad N=248$

The factors accounted for cumulative variance of $57.692 \%$.

All correlations significant at 0.01 level

Source: Author's calculation 
The first factor is named 'Job centrality' as items exhibited properties of providing importance to the job and organization. This is in tune with the definition of work centrality provided by Kularathna \& Adhikaram (2011) "moral importance given to work over other aspects of life". The second factor was named "Self identity" based on characteristics that set individual apart due to his/her uniqueness. This is based on the definition of identity (VanStaden, 2005). The third factor was named "Person-organization fit", as it denoted individual-organization compatibility. This naming is in line with the description of Kristof (1996). The factor "Job fit" is named so, as the items indicated positive association between individual and job. The fifth factor, "Collective identity" denotes the characteristic of the individual to be wholeheartedly part of groups within organizations. This is in tandem with Johnson et al., (2012). The EFA was followed by Confirmatory Factor Analysis.

\section{Confirmatory Factor Analysis (CFA)}

CFA was done with AMOS software. CFA can help in confirming the factor structure, and to judge the significance of the generated model (Kaur \& Sharma, 2015). Table 3 provides the details of the factor solution of WIS.

Table 3. Fit index of WIS

\begin{tabular}{|c|c|c|c|}
\hline Fit index & $\begin{array}{l}\text { Model } \\
\text { value }\end{array}$ & $\begin{array}{l}\text { Recommended } \\
\text { value }\end{array}$ & Reference \\
\hline $\begin{array}{l}\text { Chi-square } \chi^{2 / / d f} \text { (Chi-square } \\
\text { probability) }\end{array}$ & 2.33 & $<5.00$ & Bentler (1989) \\
\hline Goodness of fit index (GFI) & 0.87 & $>0.90$ & Hair, et al (2010) \\
\hline $\begin{array}{l}\text { Adjusted goodness of fit index } \\
\text { (AGFI) }\end{array}$ & 0.84 & $>.80$ & Gefen, et al (2003) \\
\hline $\begin{array}{l}\text { Root mean square error of } \\
\text { approximation (RMSEA) }\end{array}$ & 0.07 & $<0.07$ & Steiger (2007) \\
\hline Comparative fit index (CFI) & 0.86 & $>0.90$ & Bentler (1992) \\
\hline Normed fit index (NFI) & 0.78 & $>0.80$ & Hooper, et al (2008) \\
\hline Root mean square residual (RMSR) & 0.05 & $<0.05$ & $\begin{array}{c}\text { Byrne (1998); } \\
\text { Diamantopoulos \& } \\
\text { Siguaw (2000) }\end{array}$ \\
\hline Parsimony normed fit index (PNFI) & 0.66 & $\begin{array}{l}\text { No limit but near } \\
\text { to } 0.50\end{array}$ & $\begin{array}{c}\text { Kelloway (1998); Sharma } \\
\text { (1996) }\end{array}$ \\
\hline $\begin{array}{l}\text { Parsimony goodness of fit index } \\
\text { (PGFI) }\end{array}$ & 0.68 & $\begin{array}{l}\text { No limit but near } \\
\text { to } 0.50\end{array}$ & $\begin{array}{c}\text { Kelloway, 1998; Sharma, } \\
1996\end{array}$ \\
\hline Coefficient alpha & 0.89 & $>0.70$ & Nunnally (1978) \\
\hline
\end{tabular}

Source: Author's claculation

There existed problems about the strength of the measurement model due to a number of fit issues. For instance, the model value of GFI, RMSEA, CFI, RMR and NFI are below the recommended values. This warrants further purification of the scale. For a model to be correct, the standardized residual covariances exhibited in the symmetric matrix are expected to have a standard normal distribution, and most of the values should be less than two (Kelloway, 1998; Sharma, 1996).

An examination of the standardized residual covariances of the default model revealed three items with values above two. For a perfect fit to emerge, these items were dropped and CFA was redone. The factor solution based on the modified WIS (with a total of 18 after 
dropping 3 items) is presented in Table 4. This iterative process facilitated in a stronger fitting model.

Table 4. Modified Fit index

\begin{tabular}{lcc}
\hline \multicolumn{1}{c}{ Fit index } & Model value & Recommended value \\
\hline Chi-square/df (Chi-square probability) & 2.02 & $<5.00$ \\
\hline GFI & 0.90 & $>0.90$ \\
\hline AGFI & 0.87 & $>0.80$ \\
\hline RMSEA & 0.06 & $<0.08$ \\
\hline CFI & 0.90 & $>0.90$ \\
\hline NFI & 0.82 & $<0.80$ \\
\hline RMSR) & 0.04 & $<0.05$ \\
\hline PNFI & 0.67 & Near to 0.50 \\
\hline PGFI & 0.66 & Near to 0.50 \\
\hline Coefficient alpha & 0.87 & $>0.70$ \\
\hline
\end{tabular}

Source: Author`s claculation

For structural suitability and acceptance, the model values of RMSEA, RMSR, GFI, AGFI and NFI need to be considered (Byrne, 2010; Kline, 2005). The model values for all required fit indices are within in threshold value or rules-of-thump, and are hence superior. Though a number of fit indices are included in Table 4, according to Hooper et al., (2008), it is sensible even if only the Chi-Square statistic, RMSEA and its associated confidence intervals like SRMR, CFI and one parsimony fit index like PNFI are reported. These indices are insensitive to factors like sample size, parameter estimates and model misspecification. All these indices in the default model present perfect fit.

The path diagram is presented as Figure 1. It can be seen that the factor loadings of the items ranged between .52 and .78 . The inter-factor-correlation revealed that all five factors correlate between them significantly at 0.01 level. The $r$ varied between .339 and .513 . The factor to total scores also exhibited significant correlations. Data pertaining to mean, SD and factor correlations are presented in Table 5.

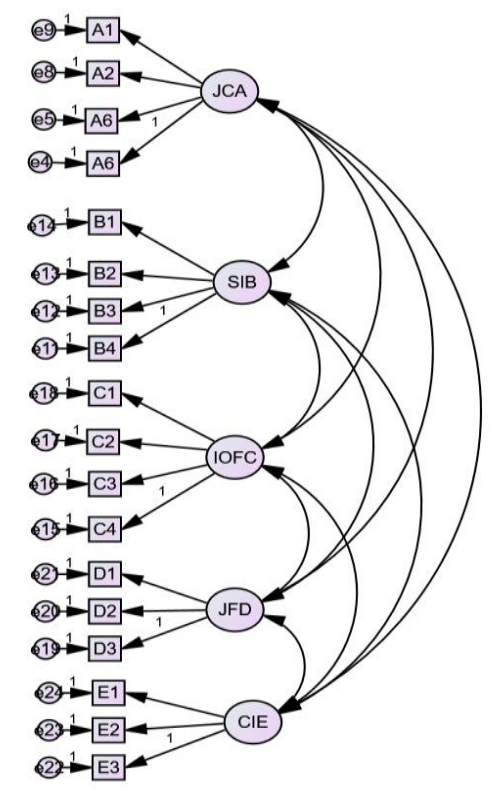

Figure 1. Path diagram of WIS

Note: The details of the items are as pet the details presented in Table 4 
Table 5. Scores of Inter-factor correlation

\begin{tabular}{lcccccccc}
\hline & Mean & S.D. & JCA & SIB & IOFC & JFD & CIE & WIS \\
\hline A(JCA) & 14.95 & 2.83 & 1 & .462 & .496 & .521 & .473 & .806 \\
\hline B(SIB) & 14.50 & 2.74 & & 1 & .391 & .513 & .444 & .760 \\
\hline C(IOFC) & 15.32 & 2.83 & & & 1 & .339 & .478 & .749 \\
\hline D(JFD) & 12.29 & 1.81 & & & & 1 & .456 & .714 \\
\hline E (CIE) & 12.47 & 1.71 & & & & & 1 & .716 \\
\hline WIS & 69.53 & 9.00 & & & & & & 1 \\
\hline
\end{tabular}

Note: $\mathrm{N}=248$ All correlations significant at 0.01 level

Source: Author's claculation

The present study, through following time tested and vigorous standards has succeeded in developing a multi-dimensional reliable and valid tool (WIS) for the measurement of WI.

\section{Validity and Reliability}

The utility of any scale depends on its demonstration of required reliability and validity. Elaborate efforts were put to establish the validity and reliability of the scale.

\section{Validity}

Validation is an important part that requires care and caution from the part of the investigator (Spector, 1992), as it cannot be measured by any statistical tool (Crocker \& Algina, 1986). The focus of validation has to be on the inferences that are derived, and they should be "appropriate, meaningful, and useful" (Gregory, 1992). Validity can take the form of content, construct, criterion, or consequential (Messick, 1995).

\section{Face and Content Validity}

Face and content validities were assessed with the help of experts in the related field. The consulted experts were of the opinion that the items of WIS appear to measure the construct of workplace identity of the respondents, which confirms face and content validity.

\section{Construct Validity}

Construct validity confirms that a scale "measures what it is purported to measure" (Hinkin, 1998). It demonstrates that the scale is scientifically strong and has the required quality (Scmitt \& Klimoski, 1991). Construct validity can be assessed through the examination of convergent validity. A measure demonstrates adequate convergent validity if it is associated with other scales that measure the same construct (Hinkin, 1998; Kumar \& Beyerlein, 1991). Extreme care was exercised during creation of item pool so that data reduction would not hamper in arriving at the intended factors. As stipulated by Hinkin (1998), to ensure convergent validity, certain known scales were considered while developing the items. Some existing known scales used for item development include Banerjee (2013), Bothma \& Roodt (2012), Cortini (2016), etc.

For assessing construct validity, the scores of WIS were correlated with another tool (Banerjee, 2013) that purports to measure WI. The analysis presented a very high correlation of .728. This confirms that WIS qualifies for remarkable construct and convergent validity. 
The results have thus demonstrated that WIS has acceptable levels of factorial validity and the required internal consistency among a sample studied. It would be ideal for researchers to test the generalizability of WIS among varying populations of interest (Anastasi \& Urbina, 1997; Schutz, 1994).

\section{Reliability}

Reliability maximizes the power of the scale, since it is capable of assuring precision (Kerlinger, 1986) and consistency (DeVellis, 1991). It is a precursor to validity. According to Crocker \& Algina (1986) and Henson (2001), if there are high inter-item correlations, it can provide an inference of reliability. Further, the Cronbach $\alpha$ satisfies the rule of the thump stipulated by Nunnally (1978). Though popular among researchers, now there are considerable arguments against Cronbach $\alpha$. Those against its usage argue that it is too sensitive to the number of items in the measure. Alternatively, they support using raw mean of the inter-item correlation for measuring internal consistency (Briggs \& Cheek, 1986). According to Briggs \& Cheek (1986) "the optimal level of homogeneity occurs when the mean inter-item correlation is in the .20 to .40 range". However, Clark \& Watson (1995) suggested a range of .15 to .50 for broad, and .40 to .50 for narrow constructs.

\section{Limitations of the study}

No study is without limitation, and the present one is no exception to this. A major limitation was that the data used for the study were not longitudinal in nature. Due to this the analysis had to be limited to concurrent validity. Had the data been longitudinal in nature, it would have been possible to check predictive validity too. This could have facilitated in providing a direction towards predicting whether an employee would be increasing his/her level of WI in future. Another possible limitation of the study was that it had completely relied on self-reported data. There is a possibility that a few samples would have responded in a socially desirable manner. For instance, some respondent would have overstated themselves with respect to their work providing meaning to their life. This may also be the case of the perceived freedom at work. There is the possibility of either over or under stating the response. Though the tests of convergent and concurrent validity had indicated that WIS has worked as it ought to have, there is the possibility for the analyses having been influenced to certain extend by socially desirable responses. However, this possibility does exist for almost all studies that use self-reported data (Dew \& Xiao, 2011).

Another possible limitation could be the so called experimenter or observer effect (Rosenthal, 1976) - a bias associated with the influence of researcher on the interpretation of the results. However, since all prescribed threshold values and rules-of-thump associated with validation of tools have been followed without fail, it can be considered that limitations associated with experimenter effect has not crept in.

WIS could require additional refinements, and researchers need to use it judiciously. Refining could me made based on the socio-cultural and political backgrounds, uniqueness of certain organizations, etc. Further, WIS is not constructed as a checklist to test WI. Rather it would serve as a brief scale that could help researchers to measure WI. Though the scale has successfully demonstrates reliability and validity on a cross section of sample, there could be possible variations for certain sub-groups which needs further examination. Future researchers could possibly add a new dimension by directing their studies towards this direction. 


\section{Conclusion}

WI significantly influences employee behaviour, and the resultant work and organizational outcomes (Amiot, et al., 2007). It can positively impact organisational performance of individuals in groups (Agostino, 2004; Wayne et al., 2006) and employee behaviour "impacting the subjective work and objective organisational outcomes" (Amiot et al., 2007). A fair review of related literature showed that there is paucity of a scientifically developed tool to measure WI, which would probably prevent accumulation of empirical data about it.

The study aimed at developing a valid and reliable scale that can be used to measure WI. The initial WIS had a pool of 28 items. After EFA and CFA, the final WIS consisting of 18 items exhibited perfect model fit as per stipulations (Link to WIS is provided in the Annexure). Since WIS enjoys good validity and reliability, it is an ideal tool to measure WI. The study has succeeded in constructing a multi-dimensional scale and validating it using a broad cross-section of representative data. WIS offers researchers and scholars with a reliable and valid tool for measurement of WI. Based on requirement researchers and scholarsare at liberty to use either the whole or part of the scale. Revisions of the scale could also be undertaken freely as deemed fit, as long as citation of this study is done. The author will be highly obliged if further literature is added by researchers and academicians by using WIS.

\section{References}

Abrams, D., \& Hogg, M. A. (2004). Meta-theory: Lessons from social identity research. Personality and Social Psychology Review, 8 (2), 98-106. doi: 10.1207/s15327957pspr0802_2.

Agostino, J. (2004). Workplace identity. Unpublished thesis Doctor of Business Administration, Swinburne University of Technology, Hawthorn, Victoria, Australia.

Albert, S., Ashforth, B. E., \& Dutton, J. E. (2000). Organisational identity and identification: Charting new waters and building new bridges. The Academy of Management Review, 25(1), 13-17. doi: 10.5465/AMR.2000.2791600.

Alvesson, M. and Willmott, H. (2002). Producing the appropriate individual: identity regulation as organizational control. Organization, 15 (1), 5-28.

Amiot, C. E., de la Sablonnière, R., Terry, D. J., \& Smith, J. R. (2007). Integration of social identities in the self: Toward a cognitive-developmental model. Personality and Social Psychology Review, 11, 364-388. doi: 10.1177/10888 68307304091.

Anastasi, A. (1976). Psychological testing, 4th ed. New York: Macmillan.

Ashforth, B. E., \& Kreiner, G. E. (1999). How can you do it? Dirty work and the challenge of constructing a positive identity. The Academy of Management Review, 24 (3), 413-434.

Ashforth, B.E., \& Mael, F. (1989). Social identity theory and the organisation. The Academy of Management Review, 14 (1), 20-39.

Bajerjee, D. (2013). Workplace Identities of Women in the US Labor Market. Sociology Mind, 3(1), 19-24. http://dx.doi.org/10.4236/sm.2013.31004

Bauman, Z. (2004). Identity, UK: Polity, Cambridge.

Bearden, W. O., Netemeyer, R. G. \& Mobley, M .F. (1993). Handbook of Marketing Scales. Newbury Park, CA: Sage Publications.

Bothma, F. C. (2011). The consequences of employees' WI. Unpublished doctoral thesis, University of Johannesburg, Johannesburg. 
Bothma, F. C., \& Roodt, G. (2013). Work-based identity and work engagement as potential antecedents of task performance and turnover intention: Unravelling a complex relationship. SA Journal of Industrial Psychology, $38(1)$. http://dx.doi.org/10.4102/sajip.v38i1.893

Bothma, F.C., Lloyd, S. \& Khapova, S. (2015). Work Identity: Clarifying the Concept in Jansen, P. G. W. \& Roodt G. (eds.), Conceptualising and Measuring Work Identity, Dordrecht: Springer Science+Business Media. doi: 10.1007/978-94-017-9242-4_2

Boyle, G. J. (1991). Does item homogeneity indicate internal inconsistency or item redundancy in psychometric scales? Personality and Individual Differences, 12(3), 291-294.

Briggs, S. R., \& Cheek, J. M. (1986). The role of factor analysis in the evaluation of personality scales. Journal of Personality, 54, 106-148.

Brown, A. and Bimrose, J. (2018). Learning and Identity Development at Work. In: Milana M., Webb S., Holford J., Waller R., Jarvis P. (eds) The Palgrave International Handbook on Adult and Lifelong Education and Learning. Palgrave Macmillan, London.

Buche, M. W. (2003). IT professional work Identity: Construct and outcomes. Unpublished Dissertation, University of Kansas, Lawrence, KS.

Buche, M. W. (2008). Influence of gender on IT professional work identity: Outcomes from a PLS study. Retrieved from http://portal.acm.org/citation.cfm?id=1355272

Burke, P. J. (1991). Identity processes and social stress. American Sociological Review, 56 (6), 836-849. doi: 10.2307/2096259.

Byrne, B.M. (1998). Structural Equation Modeling with LISREL, PRELIS and SIMPLIS: Basic Concepts, Applications and Programming. Mahwah, New Jersey: Lawrence Erlbaum Associates.

Caza, B. \& Wilson, M. (2009). Me, Myself and I: The benefits of work identity complexity. Exploring positive identities and organizations: Building a theoretical and research foundation, 99-112, New York: Routledge.

Churchill, G. A. (1979). A Paradigm for Developing Better Measures for Marketing Constructs, Journal of Marketing Research, 16, 64-73.

Clark, L. A., \& Watson, D. (1995). Constructing validity: Basic issues in objective scale development. Psychological Assessment, 7, 309-319.

Comrey, A. L., \& Lee, H. B. (1992). A first course in factor analysis. Hillsdale, NJ: Erlbaum

Cook, J. D., Hepworth, S. J., Wall, T. D. \& Warr, P. B. (1981). The experience of work. San Diego: Academic Press.

Cortini, M. (2016). Workplace identity as a mediator in the relationship between learning climate and job satisfaction during apprenticeship Suggestions for HR practitioners. Journal of Workplace Learning, 28 (2), 54-65. Doi: 10.1108/JWL-12-2015-0093

Cronbach, L. J. \& Meehl, P. C (1955). Construct validity in psychological tests, Psychological Bulletin, 52, 281-302.

Dew, J. \& Xiao, J. J. (2011). The Financial Management Behavior Scale: Development and Validation. Journal of Financial Counseling and Planning, 22 (1), 43-59.

Diamantopoulos, A. \& Siguaw, J. A. (2000). Introducing LISREL. London: Sage Publications.

Dutton, J. E., Dukerich, J. M. and Harquail, C. V. (1994), Organizational images and member identification, Administrative Science Quarterly, 39 (2), 239-263.

Dutton, J. E., Roberts L. M. \& Bednar, J. (2010). Pathways for positive identity construction at work: Four types of positive identity and building of social resources. Academy of Management Review, 35 (2), 265-293. 
Elsbach, K.D. (2006), Perceptual biases and misinterpretation of artifacts, in Rafaeli, A. and Pratt, M.G. (Eds), Artifacts and Organizations: Beyond Mere Symbolism, Lawrence Erlbaum, Mahwah, NJ.

Fugate, M., Kinicki, A. J., \& Ashforth, B. E. (2004). Employability: A psycho-social construct, its dimensions and applications. Journal of Vocational Behavior, 65(1), 14-38. doi:10.1016/j.jvb.2003.10.005.

Giddens, A. (1991). Modernity and Self-Identity, Cambridge, UK: Polity.

Hegde, S. (2016), Challenges Posed by Alien Culture Diffusion for Employees of Call Centers in Mumbai. International Letters of Social and Humanistic Sciences, 66, 81-95.

Hewitt, J. P. (1989). Dilemmas of the American self, Philadelphia: Temple University Press.

Hinkin, T. R. (1995). A review of scale development practices in the study of organizations, Journal of Management, 21(5), 967-988.

Hinkin, T. R. (1998). A brief tutorial on the development of measures for use in survey questionnaires. Organizational Research Methods, 1, 104. doi: 10.1177/109442819800100106.

Hoelter, J, W. (1983). The analysis of covariance structures: Goodness-of-fit indices. Sociological Methods and Research, 11,325-344.

Hogg, M. A., \& Terry, D. J. (2000). Social identity and self-categorization processes in organisational contexts. Academy of Management Review, 25(1), 121-140.

Hogg, M. A., Terry, D. J., \& White, K. M. (1995). A tale of two theories: A critical comparison of identity theory with social identity theory. Social Psychology Quarterly, 58(4), 255269. doi: $10.2307 / 2787127$.

Holt, D. T., Armenakis, A. A., Field, H. S., \& Harris, S. G. (2007). Readiness for Organizational Change: The Systematic Development of a Scale. Journal of Applied Behavioral Science, 43 (2), 232-255.

Hooper, D., Coughlan, J., \& Mullen, M. (2008). Structural Equation Modelling: Guidelines for Determining Model Fit. Electronic Journal of Business Research Methods, 6 (1), 53-60.

Kaiser, H. F. (1974). An index of factorial simplicity. Psychometrica, 39, 31-36.

Kaur, J., \& Sharma, S. K. (2015). Internal marketing: Scale development and validation. VisionThe Journal of Business Perspective, 19 (3) 236-247.

Kelloway, E Kevin (1998). Using LISREL for Structural Equation Modeling: A Researcher's Guide, New York: Sage Publications.

Kim, J., \& Mueller, C. W. (1978). Introduction to Factor Analysis: What is it and How to Do it, Beverly Hills CA: Sage.

Kirpal, S. (2004). Researching work identities in European context. Career Development International, 9(3), 199-221. doi: 10.1108/13620430410535823

Kline, P. (2002). An easy guide to factor analysis. London: Routledge.

Kristof, A. (1996). Person-organization fit: An integrative review of its conceptualizations, measurements and implications, Personnel Psychology, 49, 1-49.

Kularathna, M., \& Adhikaram, A. (2011). Role of identity in creating work centrality among young Sri Lankan managers in the era of late capitalism. International Research Conference on Management and Finance, 1316-1327, University of Colombo, Sri Lanka.

Kumar, K., \& Beyerlein, M. (1991). Construction and Validation of an Instrument for Measuring Ingratiatory Behaviors in Organizational Settings, Journal of Applied Psychology, 76 (5), 619-627. 
Lauver, K. J., \& Kristof-Brown, A. (2001). Distinguishing between employees' perceptions of person-job and person-organization fit. Journal of Vocational Behavior, 59, 454470. http://dx.doi.org/10.1006/jvbe.2001.1807

Lenth, R. V. (2001). Some Practical Guidelines for Effective Sample Size Determination, The American Statistician, 55(3), 187-193.

Lissitz, R. W., \& Green, S. B. (1975). Effect of the number of scale points on reliability: A Monte Carlo approach. Journal of Applied Psychology, 60,10-13.

Lloyd, S., Roodt, G., \& Odendaal, A. (2011). Critical elements in defining work-based identity in post-apartheid South Africa. SA Journal of Industrial Psychology, 37(1), doi: 10.4102/sajip.v37i1.894.

Lodahl, T. M., \& Kejner, M. (1965). The definition and measurement of job involvement. Journal of Applied Psychology, 49, 24-33. http://dx.doi.org/10.1037/h0021692,

Mael, F., \& Ashforth, B.E. (1992). Alumni and their alma mater: A partial test of the reformulated model of organisation. Journal of Organisational Behaviour, 13, 103124. http://dx.doi.org/10.1002/job.4030130202

Nunnally, J. C. (1978). Psychometric theory (2nd Ed.), New York: McGraw-Hill Book Company.

Odeh, R. E., \& Fox, M. (1991). Sample Size Choice: Charts for Experiments with Linear Models (2nd ed.), New York: Marcel Dekker.

Olkkonen, R., \& Saastamoinen, K. (2000). SPSS Perusopas markkinatutkijoille (SPSS Basic Guide for Market Researchers) Publications of the Turku School of Economics and Business Administration, Series B-1, 2002.

Rapoport, T, (1989). Experimentation and control: A conceptual framework for the comparative analysis of socialization agencies. Human Relations, 42, 957-973.

Riemenschneider, C. K., Buche, M. W., \& Armstrong, D. J. (2019). He Said, She Said: Communications Theory of Identity and The Challenges Men Face in The Information Systems Workplace, The DATA BASE for Advances in Information Systems, 50 (3), 85115.

Roodt, G. (1997). Theoretical and empirical linkages between work-related commitment foci. $S$ A Journal of Industrial Psychology, 23(2), 6-3. http://dx.doi.org/10.4102/sajip.v23i2.624

Rosenthal, R. (1976). Experimenter Effects in Behavioral Research. New York: John Wiley.

Rummel, R. J. (1970). Applied factor analysis, Evanston, IL: Northwestern University Press.

Sandhya, S., \& Sulphey, M. M. (2019). An assessment of contribution of employee engagement, psychological contract and psychological empowerment towards turnover intentions of IT employees. International Journal of Environment, Workplace and Employment, 5 (1), 22-31. https://doi.org/10.1504/IJEWE.2019.097186

Sandhya, S. \& Sulphey, M. M. (2020). Influence of Empowerment, Psychological Contract and Employee engagement on Voluntary Turnover Intentions, International Journal of Productivity and Performance Management, https://doi.org/10.1108/IJPPM-04-2019$\underline{0189}$

Schriesheim, C. A. \& Eisenbach, R. J. (1991). Item wording effects on EFA results: An experimental investigation, Pp. 396-398 in Proceedings of the 1990 Southern Management Association annual meetings. 
Schwab, D. P. (1980). Construct validity in organization behavior, in B. M, Staw \& L. L, Cummings (Eds,), Research in organizational behavior, Vol, 2, Greenwich, CT: JAI Press.

Serafini, T. E., Maitland, S. B., \& Adams, G. R. (2006). The functions of identity scale: Revisions, validation and model testing. Poster presented at the Biennial Meeting of the Society for Research on Adolescence, San Francisco, California.

Sharma, S. (1996). Applied Multivariate Techniques, New York: John Wiley \& Sons.

Staples, C. L., Schwalbe, M. L., \& Gecas, V. (1984). Social class, occupational conditions, and efficacy-based self-esteem. Sociological Perspectives, 27, 85-109. doi: 10.2307/1389238.

Steiger, J. H. (2007). Understanding the limitations of global fit assessment in structural equation modelling. Personality and Individual Differences, 42 (5), 893-98.

Stets, J. E. (2005). Examining emotions in identity theory. Social Psychology Quarterly, 68(1), 39-74. doi: 10.1177/019027250506800104.

Stets, J. E., \& Harrod, M. M. (2004). Verifi cation across multiple identities: The role of status. Social Psychology Quarterly, 67(2), 155-171. doi: 10.1177/019027250406700203.

Stone, E. (1978). Research methods in organizational behavior, Glenview, IL: Scott, Foresman.

Sulphey, M. M. \& Alkahtani, N. S. (2017). Organizational ambidexterity as a prelude to corporate sustainability, Journal of Security and Sustainability Issues, 7 (2), 335-347. https://doi.org/10.9770/jssi.2017.7.2(13).

Sulphey, M. M. \& Faridi, M. R. (2020). Consumer Ethnocentrism: Validation of CETSCALE and Measurement among Saudi Citizens, International Journal of Electronic Marketing and Retailing, (forthcoming)

Sulphey, M. M. (2014). Construction \& Validation of Employee Wellness Questionnaire, Indian Journal of Industrial Relations, 49(4), 690-700.

Sulphey, M. M. (2015). Construction and Validation of Learning Organization Questionnaire (LOQ). JAMI, 4(1), 35-44.

Sulphey, M.M. (2019). The concept of workplace identity, its evolution, antecedents and development.International Journal of Environment, Workplace and Employment, 5(2), 151-168. http://doi.org/10.1504/IJEWE.2019.10019877.

Tabachnick, B. G., \& Fidell, L. S. (2001). Using multivariate statistics, (4th ed.). New York: Harper \& Row.

Tossell, C., Kortum, P., Shepard, C. Rahmati, A. and Zhong, L. (2015). Exploring Smartphone Addiction: Insights from Long-Term Telemetric Behavioral Measures, IJIM, 9(2), 37-43. http://dx.doi.org/10.3991/ijim.v9i2.4300

Turner, J. C. (1987). Rediscovering the social group: A self-categorization theory. New York: Basil Blackwell.

Van Laar, C., Meeussen, L., Veldman, J., Van Grootel, S., Sterk, N., \& Jacobs, C. (2019). Coping with Stigma in the Workplace: Understanding the Role of Threat Regulation, Supportive Factors, and Potential Hidden Costs. Frontiers in psychology, 10, 1879. https://doi.org/10.3389/fpsyg.2019.01879

Van Staden, A. (2005). A psycho-educational model to facilitate the self-development and mental health of the pre-professional classical dancer as individual and performer. Unpublished dissertation, University of Johannesburg, Johannesburg.

Viswanathan, M. (1993). Measurement of individual differences in preference for numerical information. Journal of Applied Psychology, 78, 741-752. 
Walsh, K. (2000). Delivering expertise: Identity and relationship building in professional services. Doctoral Dissertation, Boston College, Chestnut Hill, Massachusetts.

Walsh, K., \& Gordon, J. R. (2008). Creating an individual work identity. Human Resource Management Review, 18 (1), 46-61.

Wayne, J. H., Randel, A. E., \& Stevens, J. (2006). The role of identity and work-family support in work-family enrichment and its work-related consequences. Journal of Vocational Behavior, 69, 445-461.

Worth, N. (2016). Who we are at work: millennial women, everyday inequalities and insecure work? Gender Place \& Culture, 23(9), 1302-1314. http://dx.doi.org/10.1080/0966369X.2016.1160037

\section{Annexure}

Link to the questionnaire $\quad$ - $\quad$ https://osf.io/97z4k/quickfiles 